\title{
Dating on its own cannot resolve hominin occupation patterns
}

To the Editor - Cortés-Sánchez et al. ${ }^{1}$ argue that anatomically modern humans (AMHs) arrived in the southern Iberian Peninsula by around $\sim 43.0-40.8$ calibrated thousand years before the present (cal ka BP). This postulates an almost simultaneous arrival of AMHs in Southern Iberia and other parts of Western Europe, contravening hypotheses of the long persistence of Neanderthals in this region ${ }^{2-4}$. The authors' argument is based on 17 radiometric dates, coupled with the proposal that layer $\mathrm{Bj} 13$ from the site of Bajondillo (Málaga, Spain) can be attributed to the Early Aurignacian. Although their dating methods and results are well-defended, the authors fall short on the technological description and definition of the Bj13 lithic assemblage. Moreover, it is unclear from the manuscript whether the dates are used to justify the reclassification of the lithics from $\mathrm{Bj} 13$. It must be borne in mind that the main debate on the Neanderthal to AMH transition is performed through the interpretation of the technological industries owing to the lack of skeletal remains.

The Bj13 assemblage has been previously described in a number of publications as an ambiguous technological assemblage with both characteristic Mousterian flake blanks and related blanks from the Upper Palaeolithic ${ }^{5,6}$.

Cortés-Sánchez et al. agree in the paper that the lithic assemblage does not offer enough of a guarantee to be clearly attributed to the 'Proto-Aurignacian or Early Aurignacian'. Therefore, the major problem is with the description and definition of this lithic assemblage. If the assemblage cannot be clearly attributed to the ProtoAurignacian or Early Aurignacian, why should it be forced to do so? In fact, several equally plausible scenarios exist that could explain the lithic assemblage. First, if the layer represents an industry that is clearly blade-related but also has technological trends that are different from other defined Proto-Aurignacian assemblages, then it should be defined differently, perhaps as a new and different modality of the Upper Palaeolithic that was previously undetected. This would not be surprising; it happens all along Europe with the initial arrival of AMHs. Indeed, other Early Upper Palaeolithic contexts in southern Iberia show well-developed flake strategies that differ from other European contexts ${ }^{8}$. The second possibility could be that a Mousterian layer incorporates reduction sequences of blades as a technological strategy. Demonstrating this would require a detailed technological description. With the evidence given in the publication, verifying either of these two possibilities seems quite difficult because, basically, we see some putative bladelet cores in a set of elongated flakes which could belong to any Final Pleistocene Palaeolithic assemblage.

The third possibility could be sedimentological mixing between a Mousterian and an Early Upper Palaeolithic layer. Indeed, $\mathrm{Bj} / 13$ has been reported to be in direct stratigraphical contact with $\mathrm{Bj} 11$ (Upper Palaeolithic layer) and even related to solifluxion processes ${ }^{5}$. The manuscript ignores this crucial aspect, the scrutiny of which is a must in any cave environment owing to their complex taphonomies.

In the absence of identifiable skeletal material, claims of shifting hominin occupation patterns rest on three independent lines of research: verifiable attributions of stratigraphically contextualized lithics assemblages, accurate palaeoclimatic frameworks and radiometric dating. Cortés-Sánchez et al. do not satisfactorily link the $\mathrm{Bj} 13$ assemblage to the Aurignacian and instead allow the dates to dictate the interpretation. As a result, their argument stands on only one leg, making it unstable at best.

\section{Paloma de la Peña}

Evolutionary Studies Institute \& School of Geography, Archaeology and Environmental Studies, University of the Witwatersrand, Johannesburg, South Africa. e-mail:paloma.delapenya@gmail.com

Published online: 15 April 2019 https://doi.org/10.1038/s41559-019-0886-2

References

1. Cortés-Sánchez, M. et al. Nat. Ecol. Evol. 3, 207-212 (2019).

2. Vega Toscano, L.G. El Paleolítico Medio del Sureste Español y Andalucía Oriental. $\mathrm{PhD}$ thesis, Universidad Complutense de Madrid (1988).

3. Finlayson, C. et al. Nature 443, 850-853 (2006).

4. Zilhão, J. et al. Heliyon 3, e00435 (2017).

5. Cortés-Sánchez, M. El Paleolítico Medio y Superior en el Sector Central de Andalucía (Córdoba y Málaga) (Ministerio de Cultura, Secretarîa General Técnica, 2007).

6. Cortés-Sánchez, M. in Cueva Bajondillo (Torremolinos). Secuencia cronocultural y paleoambiental del Cuaternario reciente en la Bahía de Málaga (ed. Cortés-Sánchez, M.) 93-138 (Centro de ediciones de la Diputación de Málaga, 2007).

7. Pastoors, A. \& Peresani, M. (eds.) Flakes Not Blades: the Role of Flake Production at the Onset of the Upper Palaeolithic in Europe, Mettmann (Wissenschaftliche Schriften des Neanderthal Museums 5, 2012).

8. de la Peña, P. Quat. Int. 318, 68-89 (2013).

Acknowledgements

I would like to thank J. Choiniere and D. Witelson for their valuable help and advice in the English editing of this text. I thank them both and retain responsibilities for my arguments.

Competing interests

The author declares no competing interests. 